\title{
Meta-Analysis of the Implementation of E-Modules and the Effectiveness of Using Chemical Bonding E-Modules Based on Scientific Approaches Against Student X Learning Outcomes in Pariaman City
}

\author{
Gia Aprina Putri, Indang Dewata, Budhi Oktavia, Desy Kurniawati Chemistry Education, \\ Faculty of Mathematics and Natural Sciences Padang State University \\ Jln. Prof. Dr. Hamka Air Tawar, Padang, 25131, Indonesia
}

\begin{abstract}
This study aims to reveal the effectiveness of chemical bond e-modules on the learning outcomes of class X high school students in Pariaman City. This type of research used is quasi-experimental research with a non-equivalent control group design. The population in this study was taken from three levels of UN scores (high, medium, and low) taken from the West Sumatra Province Education Office data, the population of which is grade $X$ MIPA SMAN 1 Pariaman, X MIPA SMAN 4 Pariaman, and $X$ MIPA SMAN 6 Pariaman . The research sample was taken using purposive sampling technique. The sample for SMAN 1 Pariaman as an experimental class is class X MIPA 7 and X MIPA 6 as a control class. The sample for SMAN 4 Pariaman as an experimental class is X MIPA 1 and X MIPA 2 as a control class. The sample for SMAN 6 Pariaman as the experimental class is X MIPA 2 and X MIPA 1 as the control class. The research instrument used was a student learning achievement test consisting of an initial test (pretest) and final test (posttest) and in the form of 20 objective questions. The results showed that there were differences in learning outcomes between the experimental class and the control class. This is evidenced by the average posttest score of the experimental class in each school is 87.65 for SMAN 1 Pariaman, 85.38 for SMAN 4 Pariaman, and 86.75 for SMAN 6 Pariaman while the control class is $\mathbf{7 7 . 7 6}$ for SMAN 1 Pariaman, 77.12 for SMAN 4 Pariaman, and and 76.04 for 6 Pariaman High School. Based on data analysis, it shows that the sample is normally distributed and homogeneous so that t-test can be performed and the value of $t \geq t 1-\alpha$ is obtained for SMAN 1 Pariaman titung (4. 739)> t table (1.67022), SMAN 4 Pariaman titung (3.494)> ttabel (1.67203), and SMAN 6 Pariaman titung (4.129)> ttable (1.68195), then $\mathrm{HO}$ is rejected. These data prove that the experimental class learning outcomes are higher than the control class learning outcomes. This is also supported by the $\mathrm{N}$-Gain value obtained in the experimental class with $\mathrm{N}$ Gain value of 0.83 for SMAN 1 Pariaman, 0.81 for SMAN 4 Pariaman, and 0.83 for SMAN 6 Pariaman and the control class is 0.72 for SMAN 1 Pariaman, 0.72 for SMAN 14 Pariaman, and 0.71 for SMAN 6 Pariaman in the high category. This study also proves that the ranking of national examinations at state high schools in Pariaman City has no effect on student
\end{abstract}

learning outcomes. This is based on the acquisition of student learning outcomes in Pariaman 6 Public High Schools which are in the low level national rank ranking school category which has a higher value than the student learning outcomes in Pariaman 4 Public High School which are in the medium level national exam ranking school category. The results of this study are also supported by the results of a meta-analysis which states that the application of e-modules can increase effectiveness and have a positive impact on student interests and learning outcomes so that it supports students to learn independently.

Keywords:- Effectiveness, E-modules, Chemical Bonding, Learning Outcomes, Meta-Analysis.

\section{INTRODUCTION}

The Government has established the 2013 Curriculum to be applied to schools / madrasas in order to improve the quality of education. The 2013 curriculum was established as part of improving the quality of Indonesian education in all levels, which were assessed from three domains, namely: knowledge, attitudes, and skills. Learning Curriculum 2013 provides opportunities for students to learn actively, where the teacher as a facilitator or motivator, and all aspects of life can be a source of learning. The learning process in the 2013 curriculum was carried out using a scientific approach that is a studentcentered learning approach [5].

The scientific approach (scientific approah) consists of five steps including observing, questioning, collecting data (experimenting), associating (communicating), communicating

(communicating), known as 5M. The scientific approach emphasizes students to recognize and understand the subject matter that can be obtained from various sources using a scientific approach and subject information, not only depending on the information given by the teacher [7].

The 2013 curriculum demands that in the learning process use a scientific approach, teaching materials based on a scientific approach are needed, teaching materials in which there are $5 \mathrm{M}$ aspects. Teaching materials consist of a set of material systematically compiled containing the 
competencies to be achieved by students in the learning process. Some examples of teaching materials include handouts, textbooks, modules, student worksheets, models or models, audio teaching materials, interactive teaching materials, and so on. The use of teaching materials in learning can help the teacher's limitations in conveying information and the limitations of class hours. Teaching material serves as a source of learning material information as well as a source of practice questions.

Modules are a form of printed teaching materials that are designed to be studied independently by students in learning because they have been equipped with instructions for self-study. [3]. Therefore, with the development of science and technology and the implementation of the 2013 curriculum in several schools, the modules used in print can be developed to be more interactive into e-modules based on a scientific approach. E-modules are a form of presentation of independent learning materials that are arranged systematically to achieve certain learning objectives that are presented in electronic format. The emodule includes animation, audio and navigation that will make students more interactive with the material. This interactive electronic module can help the learning process which involves displaying audio visual, sound,

E-modules can be used as teaching materials in chemical materials, one of which is chemical bonds. In the 2013 curriculum the chemical bonding material was taught in class X MIA odd semester. In this chemical bonding material, students are required to understand concepts that include: stability of elements, lewis structures, ionic bonds, covalent bonds, and coordination covalent bonds. This material requires a level of understanding in analysis, for example in ion bonding. If using teaching materials in the form of printed books or worksheets, students cannot see how electrons transfer to ionic bonds because they use still images. The e-module can see how electrons transfer using animated videos, so students are more motivated to learn and can also guide students to learn independently in finding concepts.

Meta-Analysis is also carried out in the application of E-Modules on student learning by collecting, summarizing and developing some research results from international journals sourced from Elsevier publishers by identifying the main arguments or positions of articles, followed by scanning arguments to highlight the main points discussed.

Pariaman City is one of the cities of education and has a high National Examination score in 2019. One of them is education at the high school level in Pariaman City which has 6 public high schools. According to the National Examination score in 2019 which is based on the data of the West Sumatra Provincial Education Office, the National High School rankings from high to low include: SMAN 1 Pariaman (67.04), SMAN 2 Pariaman (53.31), SMAN 3 Pariaman (52.18), SMAN 4 Pariaman (47.50), SMAN 5 Pariaman (46.08), and SMAN 6 Pariaman (42.45). The data is to obtain the results of the effectiveness of emodule chemical bonds that are distributed at the high school level in the City of Pariaman, the researchers chose based on the value of the 2019 National Examination with three levels (high, medium and low).

After observation and interviews with chemistry teachers at Kota Pariaman State High School, information was obtained that chemistry teachers who were willing and interested in using varied teaching materials such as chemical bonding e-modules were SMAN 1 Pariaman, SMAN 4 Pariaman, and SMAN 6 Pariaman. Teacher expectations from this study can improve student learning outcomes because there are still students who have difficulty understanding concepts and student involvement in the learning process that is low so that there are still students having learning outcomes under the KKM. In addition, other supporting factors the school is willing to use computer labor for the process of learning chemistry by using e-modules of chemical bonds.

Dahlan's research (2016) proves that e-modules can help students understand the material because the animations in the form of videos can increase student interest in learning so as to provide a better and interesting learning experience. Then Andriani's research (2019) learning model of learning cycle $7 \mathrm{e}$ assisted by e-modules is more effective to improve the critical thinking skills of junior high school students compared to the learning model of learning cycle 7e and conventional models. Furthermore Istuningsih's research (2018) results of the analysis showed that the application of a scientific approach using emodules based on the 7E learning cycle was effectively used.

In the explanation above, researchers have developed a chemical bonding e- module based on a scientific approach and obtained a valid and practical e-module. But it has not yet been tested for effectiveness on learning outcomes. Therefore, further research is conducted to reveal the meta- analysis of the application of e-modules in the effectiveness of the use of e-modules of chemical bonds based on a scientific approach to the learning outcomes of class X students in Kota Pariaman. 


\section{RESEARCH METHODS}

The research design used was "Non Equivalent Control Group Design" research. The design of this study can be seen as follows.

\begin{tabular}{|c|c|c|c|}
\hline Group & Prelimi nary test & Treatment & Final Test \\
\hline $\begin{array}{c}\text { Experimen } \\
\text { t Class (R ') }\end{array}$ & O1 & X & O3 \\
\hline $\begin{array}{c}\text { Control } \\
\text { Class (R) }\end{array}$ & O2 & Y & O4 \\
\hline
\end{tabular}

Table 1:- Design Research

Information:

R: Samples (experiment class and control class)

$\mathrm{X}$ : Learning to use chemical bonding e-modules based on a scientific approach

Y: Learning uses school teaching materials O1: Initial test for the experimental class O2: Initial test for the control class

O3: Final test for the experimental class O4: Final test for the control class

The population in this study were all students of class $\mathrm{X}$ MIPA in SMAN 1 Pariaman, SMAN 4 Pariaman, and SMAN 6 Pariaman in the academic year 2019/2020. The sample is part of the number and characteristics possessed by the population [9].

The instrument used in this study was a test of learning outcomes, because the object of the study was student learning outcomes. Learning outcomes tests were conducted in both sample classes. Before the final test for the two sample classes a test was conducted on the questions for students who had studied chemical bonding material, from the results of the test the test questions were analyzed first, which was seen from the validity, reliability, difficulty index, and different power of the questions. The purpose of the test trials is to see whether the questions are appropriate given to the two classes of samples, after analysis 20 questions were taken for the final test of 35 test questions.

The truth of the research data can be tested using data analysis techniques, namely the N-Gain test, normality test, homogeneity test and hypothesis test. N- Gain (normalized gain) is used to determine the increase in student cognitive learning outcomes before and after learning and to determine the effectiveness of e-modules of chemical bonds. Normality test aims to see whether the research results are normally distributed or not. Homogeneity test is done to determine whether the research data has homogeneous variance or not. While this hypothesis test aims to determine whether the research hypothesis can be accepted or rejected as well as to determine the difference between the two averages between the experimental class and the control class by using the t-test.

Meta-Analysis begins with determining and studying research topics related to the E-Module. Research literature search was carried out through an internet site with Elsevier publisher sources. In general, this study uses a combination of purposive sampling method and qualitative dominant method through a mixed approach with some quantitative data whose data collection is done through a multi method approach, whereas for the Meta-Analysis Methodology of E-Module Implementation of some of these studies using the main argument by identifying the main argument or the position of the article, followed by scaning arguments to highlight the main points being discussed as well as reading and recording important matters in gathering information from research journals.

\section{RESULTS AND DISCUSSION}

E-module uses chemical bonds to express effectiveness in terms of learning outcomes by comparing the learning outcomes of experimental classes that use emodules and control classes without using e- modules. The difference in learning outcomes from the two sample classes can be seen as follows:

\section{N-Gain Test}

\begin{tabular}{|c|c|c|c|}
\hline \multirow{2}{*}{$\begin{array}{c}\text { Public } \\
\text { High } \\
\text { School } \\
\text { Pariaman }\end{array}$} & \multicolumn{2}{|c|}{ N-Gain Average } & \multirow[b]{2}{*}{ Criteria } \\
\hline & $\begin{array}{c}\text { Experi } \\
\text { mental } \\
\text { Class }\end{array}$ & $\begin{array}{c}\text { Control } \\
\text { class }\end{array}$ & \\
\hline 1 & 0.83 & 0.72 & High \\
\hline 4 & 0.81 & 0.72 & High \\
\hline 6 & 0.83 & 0.71 & High \\
\hline
\end{tabular}

Table 2:- N-Gain Test

Table 2 can be concluded that the understanding or mastery of students' concepts of chemical bond material in the experimental class is better than the control class, so that the use of e-modules of chemical bonds is effective in improving student learning outcomes.

\section{Normality test}

The normality test is carried out using the ShapiroWilk test. Decision making criteria are based if the significance value ( $\mathrm{sig})>0.05$ then the data is normally distributed and vice versa. 


\begin{tabular}{|c|c|c|c|}
\hline \multirow{2}{*}{$\begin{array}{c}\text { Public High School } \\
\text { Pariaman }\end{array}$} & \multicolumn{2}{|c|}{ Significance (Sig) } & \multirow{2}{*}{ Decision } \\
\cline { 2 - 3 } & $\begin{array}{c}\text { Experi mental } \\
\text { Class }\end{array}$ & Control class & \\
\hline 1 & 0.483 & 0.104 & $\begin{array}{c}\text { Data is normally } \\
\text { distribute d }\end{array}$ \\
\hline 4 & 0.420 & 0.649 & $\begin{array}{c}\text { Data is } \\
\text { normally distributed }\end{array}$ \\
\hline 6 & 0.216 & 0.613 & $\begin{array}{c}\text { Data is normally } \\
\text { distributed }\end{array}$ \\
\hline
\end{tabular}

Table 3:- Normality Test Results

Table 3 shows that the two sample classes have significant values (sig)>0.05. This means that the data obtained in the pretest and posttest of the sample class are normally distributed.

\section{Homogentas Test}

\begin{tabular}{|c|c|c|c|}
\hline \multirow{2}{*}{$\begin{array}{c}\text { Public } \\
\text { High } \\
\text { School } \\
\text { Pariaman }\end{array}$} & \multicolumn{2}{|c|}{ Significance (Sig) } & \multirow[b]{2}{*}{ Decision } \\
\hline & $\begin{array}{r}\text { Experi } \\
\text { mental } \\
\text { Class }\end{array}$ & $\begin{array}{c}\text { Control } \\
\text { class }\end{array}$ & \\
\hline 1 & \multicolumn{2}{|c|}{0.372} & $\begin{array}{c}\text { Homogeneous } \\
\text { variance }\end{array}$ \\
\hline 4 & \multicolumn{2}{|c|}{0601} & $\begin{array}{c}\text { Homogeneous } \\
\text { variance }\end{array}$ \\
\hline 6 & \multicolumn{2}{|c|}{0.935} & $\begin{array}{c}\text { Homogeneous } \\
\text { variance }\end{array}$ \\
\hline
\end{tabular}

Table 4:- Test Results Homogentas

Table 4 shows that the significant value obtained $>0.05$ then the pretest and posttest result data from the sample class has homogeneous variance.

\section{Hypothesis testing}

The results of the normality and homogeneity test of the learning outcomes of the two sample classes indicate that the learning outcomes data are normally distributed and have homogeneous variance. Therefore to test the hypothesis, a "t-test" or independent sample t-test is performed. Acceptance criteria if tcount $\geq t 1-\alpha$, then the null hypothesis (H0) is rejected and vice versa.

\begin{tabular}{|c|c|c|c|}
\hline \multirow{2}{*}{$\begin{array}{c}\text { Public High School } \\
\text { Pariaman }\end{array}$} & \multicolumn{2}{|c|}{ Significance (Sig) } & \multirow[b]{2}{*}{ Decision } \\
\hline & $\begin{array}{c}\text { Experi } \\
\text { mental Class }\end{array}$ & Control class & \\
\hline 1 & \multicolumn{2}{|c|}{$\begin{array}{l}\text { Thitung: } 4,739 \\
\text { t1- } \alpha: 1.67022\end{array}$} & $\begin{array}{l}\text { Reject } \\
\text { H0 }\end{array}$ \\
\hline 4 & \multicolumn{2}{|c|}{$\begin{array}{c}\text { Thitung: } 3,494 \\
\text { t1- } \alpha: 1.67203\end{array}$} & $\begin{array}{c}\text { Reject } \\
\text { H0 }\end{array}$ \\
\hline 6 & \multicolumn{2}{|c|}{$\begin{array}{c}\text { Thitung: } 4,129 \\
\text { t1- } \alpha: 1.68195\end{array}$} & $\begin{array}{c}\text { Reject } \\
\text { H0 }\end{array}$ \\
\hline
\end{tabular}

Table 5:- Test Results Hypothesis

Table 5 shows that the value of $\mathrm{t}>\mathrm{t}$ table, then $\mathrm{H} 0$ is rejected. This shows that there are differences in the learning outcomes of the experimental class and the control class, where the learning outcomes of the experimental class that use e-module chemical bonds are higher than the control class that does not use e- module chemical bonds.

The results of this study are also supported by international research in the application of E-Modules during learning. This is demonstrated by one research journal entitled "Design and development of a collaborative learning module for secondary school science in Malaysia: addressing learners needs of the use and perception of technology "[4]. The purpose of this researchto determine design and analyze student perceptions as well as effectiveness in the application of current technology science learning.

Based on the results of a meta- analysis in international journals with Elsevier publishing sources, the following data are obtained: 
ISSN No:-2456-2165

\begin{tabular}{|c|c|c|c|c|}
\hline \multirow{2}{*}{$\begin{array}{c}\text { Technology } \\
\text { Implementation }\end{array}$} & \multicolumn{4}{|c|}{ Usage Rate (\%) } \\
\cline { 2 - 4 } & 1 & 2 & 3 & 4 \\
\hline Research and Settlement Related Reference Tools & & & 19 & 9.5 \\
\hline Using CD-ROM & 56.3 & 13.9 & 17.1 & 55.7 \\
\hline Browsing & 13.3 & 19 & 15.8 & 25.3 \\
\hline $\begin{array}{c}\text { Evaluating } \\
\text { material on the internet }\end{array}$ & 39.9 & & & \\
\hline Communication tool & & & 9.5 & 11.4 \\
\hline E-mail & 67.7 & 11.4 & 13.3 & 19.6 \\
\hline Discussion & 53.8 & 13.3 & & 10.1 \\
\hline $\begin{array}{c}\text { Web Pages) } \\
\text { Pesephone } \\
\text { Discussion }\end{array}$ & 74.3 & 11.8 & 3.8 & 48.8 \\
\hline $\begin{array}{c}\text { Online text } \\
\text { messaging }\end{array}$ & 15.8 & 20.8 & 14.6 & 45.9 \\
\hline
\end{tabular}

Table 6:- Analysis of Frequency of Application of Technology in Problem Solving and Communication Tools

Information :

- Never

- Once a month

- Once a week

- Often

The results of the study found that the application of technology has a positive impact on students because it is used as a solution to problems related to references and as a communication tool or discussion forum on learning.

Based on the description above, it can be concluded that the learning outcomes in the cognitive domain of students using e- modules of chemical bonds are significantly higher than those of students who do not use e-modules of chemical bonds in the learning process. This proves that the use of e- chemical bonding modules can effectively improve student learning outcomes in Pariaman City High School and is also proven by a meta-analysis of research "Design and development of a collaborative learning module for secondary school science in Malaysia: addressing learners needs of the use and perception of technology "[4].

\section{CONCLUSION}

Based on the results of research, data processing, data analysis and meta-analysis that have been carried out it can be concluded that the use of e-modules in the chemical bonding material is effective in improving student learning outcomes in class X SMA Pariaman. This is evidenced by an increase in student learning outcomes before and after the application of e-modules and the acquisition of cognitive values by the experimental class is higher than the control class at SMAN 1 Pariaman, SMAN 4 Pariaman, and SMAN 6 Pariaman.

The results of this study are also supported by the results of a meta-analysis which states that the application of e-modules can increase effectiveness and have a positive impact on student interests and learning outcomes so that it supports students to learn independently.

\section{REFERENCES}

[1]. Andriani, S, et al. 2019. The Effectiveness of the EModule Assisted Learning Cycle 7e Model to Improve Critical Thinking Ability of Middle School Students. Journal Volume 8, No. 1, 2019, 41-48

[2]. Dahlan, W. 2016. Development of Teaching Materials in the Form of E-Modules Equipped with Animation on Circulatory System Materials for High School / MA Students. Thesis not published. Padang: UNP.

[3]. Depdinas. 2008. Guidelines for Development of Teaching Materials. Jakarta: Ministry of National Education, Directorate General of Primary and Secondary Education Management, Directorate of High School Development.

[4]. Dorothy DeWitt. 2010. Design and development of a collaborative management module for secondary school science in Malaysia: addressing learners' needs of the use and perceptions of technology. Elsevier: Procedia Social and Behavioral Sciences 2 (2010) 471-475

[5]. Fauziah, R. 2013. Scientific Learning of Basic Ectronics Oriented Problem Based Learning. Journals. INVOTEC, Volume IX, No.2, August 2011.

[6]. Istuningsih, W, et al. 2018. The Effectiveness of Scientific Approach Using E-Module Based on 7E Learning Cycle to Improve Students' Learning Outcome. International Journal of Educational Research Review.

[7]. Majid, A and Chaerul R. 2014. Scientific Approach in Curriculum Implementation 2013. Bandung: Rosdakarya.

[8]. Sugianto, Doni, Ade GA, Siscka E., Yuda M. 2013. Emodule: Multimedia Flipbook Basic Digital Engineering. INVOTEC Vol IX, No. 2.

[9]. Sugiyono 2013. Qualitative and Combative Quantitative Research Methods (Mixed Methods). Bandung: Alfabeta. 